\title{
Effects of copper mineralogy and methanobactin on cell growth and sMMO activity in Methylosinus trichosporium OB3b
}

\author{
E. Chi Fru ${ }^{1}$, N. D. Gray ${ }^{1}$, C. McCann ${ }^{1}$, J. de C. Baptista ${ }^{1}$, B. Christgen ${ }^{1}$, H. M. Talbot ${ }^{1}$, A. El Ghazouani ${ }^{2}$, \\ C. Dennison ${ }^{2}$, and D. W. Graham ${ }^{1}$ \\ ${ }^{1}$ School of Civil Engineering and Geosciences, Newcastle University, Newcastle upon Tyne, NE1 7RU, UK \\ ${ }^{2}$ Institute for Cell and Molecular Biosciences, Medical School, Newcastle University, Newcastle upon Tyne, NE2 4HH, UK
}

Received: 18 February 2011 - Published in Biogeosciences Discuss.: 18 March 2011

Revised: 27 September 2011 - Accepted: 5 October 2011 - Published: 14 October 2011

\begin{abstract}
Controls on in situ methanotroph activity are not well understood. One potentially important parameter is copper $(\mathrm{Cu})$ because it is the metal-centre of particulate methane monooxygenase (pMMO), the most active enzyme for oxidizing methane to methanol. Further, Cu-to-cell ratios influence the relative expression of pMMO versus the alternate soluble MMO (sMMO) in some species. However, most methanotroph studies only have assessed readily soluble forms of $\mathrm{Cu}$ (e.g. $\mathrm{CuCl}_{2}$ ) and there is a dearth of $\mathrm{Cu}$-related activity data for $\mathrm{Cu}$ sources more common in the environment. Here we quantified sMMO activity (as a practical indicator of $\mathrm{Cu}$ availability) and growth kinetics in Methylosinus trichosporium OB3b, an organism that expresses both pMMO and sMMO, when grown on $\mathrm{Cu}$ minerals with differing dissolution equilibria to assess how mineral type and methanobactin $(\mathrm{mb})$ might influence in situ methanotroph activity. $\mathrm{Mb}$ is a molecule produced by $\mathrm{M}$. trichosporium $\mathrm{OB} 3 \mathrm{~b}$ that has a high affinity for $\mathrm{Cu}$, reduces $\mathrm{Cu}$ toxicity, and may influence $\mathrm{Cu}$ availability in terrestrial systems. $\mathrm{CuCO}_{3} \cdot \mathrm{Cu}(\mathrm{OH})_{2}$ and $\mathrm{CuO}$ were chosen for study based on modelling data, reflecting more and less soluble minerals, respectively, and were found to affect $M$. trichosporium OB3b activity differently. Cells grew without growth lag and with active pMMO on $\mathrm{CuCO}_{3} \cdot \mathrm{Cu}(\mathrm{OH})_{2}$, regardless of the amount of mineral supplied $(<500 \mu$ moles $\mathrm{Cu}-$ total $\left.1^{-1}\right)$. The organism also grew well on $\mathrm{CuO}$; however, significant sMMO activity was retained up to $50 \mu$ moles $\mathrm{Cu}$ total $1^{-1}$, although sMMO activity was suppressed by supplemental $\mathrm{mb}$ and-or direct cell-mineral contact. $\mathrm{Mb}$ addition increased growth rates $(p<0.05)$ with both minerals. Results show mb broadly stimulates growth, but $\mathrm{Cu}$ mineralogy
\end{abstract}

Correspondence to: D. W. Graham (d.graham@ncl.ac.uk) and mb dictate whether sMMO or pMMO is active in the cells. This explains why sMMO activity has been seen in soils with high $\mathrm{Cu}$ and also has implications for predicting dominant MMO activity in terrestrial bioremediation applications.

\section{Introduction}

Copper $(\mathrm{Cu})$ is central to aerobic biological methane oxidation (Nguyen et al., 1994; Berson and Lidström, 1996; Hanson and Hanson, 1996; Murrell et al., 2000; Knapp et al., 2007) because it is the metal-centre of particulate methane monooxygenase (pMMO) (Balasubramanian et al., 2010), the most active enzyme at converting methane $\left(\mathrm{CH}_{4}\right)$ to methanol (Hanson and Hanson, 1996). Further, Cu-to-cell mass ratio regulates the expression of pMMO versus the less efficient iron-associated soluble MMO (sMMO) produced in some methanotroph species (Murrell et al., 2000). However, most studies on $\mathrm{Cu}$ and methanotrophs only have assessed readily soluble $\mathrm{Cu}$ sources (e.g. $\mathrm{CuCl}_{2}$; Fitch et al., 1993; DiSpirito et al., 1998; Choi et al., 2006), which are rarely present in nature, and only recently has methanotroph behaviour been studied using typical environmental $\mathrm{Cu}$ sources, such as solid-phase minerals (Knapp et al., 2007; Kulczycki et al., 2007, 2011). Given that solid-phase conditions strongly influence metal dissolution traits for all minerals, we propose that $\mathrm{Cu}$ mineralogy and in situ methanotroph activity must be linked, although specific relationships between $\mathrm{Cu}$-mineral dissolution and methanotroph activity are not understood.

The purpose of this study was to quantify methanotroph growth and MMO activity as a function of solid-phase $\mathrm{Cu}$ supply and the presence of methanobactin (mb; Kim et al.,

Published by Copernicus Publications on behalf of the European Geosciences Union. 
2004). $\mathrm{Mb}$ is a small $\mathrm{Cu}$-binding molecule produced by some methanotrophs that has a very high affinity for $\mathrm{Cu}(\mathrm{I})(\sim 6-$ $7 \times 10^{20} \mathrm{M}^{-1}$; Ghazouani et al., 2011) and is also involved in $\mathrm{Cu}$ uptake, toxicity suppression and other key functions in the cells (Fitch et al., 1993; Zahn and DiSpirito, 1996; DiSpirito et al., 1998; Kim et al., 2005; Choi et al., 2006; Knapp et al., 2007; Kulczycki et al., 2007; Balasubramanian and Rosenzweig, 2008; Choi et al., 2008; Kulczycki et al., 2011). Although other mbs have been noted (Krentz et al. 2010; El Ghazouani et al., 2011), only one complete structure has been elucidated, which is for the type II methanotroph, Methylosinus trichosporium OB3b (Kim et al., 2004). This $\mathrm{mb}$ resembles a peptidic siderophore (Kim et al., 2005; Graham and Kim, 2011), has a formula of $\mathrm{C}_{45} \mathrm{H}_{56} \mathrm{~N}_{10} \mathrm{O}_{16} \mathrm{~S}_{5} \mathrm{Cu}^{-}$ and an exact mass of 1215.1781 Da (Behling et al., 2008). Previous work has shown that this mb mediates pMMOrelated gene transcription in $M$. trichosporium OB3b grown in the presence of $\mathrm{Cu}$-Fe-oxides (Knapp et al., 2007) and also influences growth kinetics on Cu-doped-silicates (Kulczycki et al., 2011). However, the influence of mb on methanotroph growth and activity for other $\mathrm{Cu}$ minerals has not been assessed; especially the type of MMO activity present with differentially soluble $\mathrm{Cu}$ phases (Nriagu, 1979; Morton et al., 2000).

This work uses $M$. trichosporium OB3b to examine how different $\mathrm{Cu}$ minerals and $\mathrm{mb}$ might impact in situ methanotroph activity in terrestrial environments. First, $\mathrm{Cu}$ solubilities were calculated for different $\mathrm{Cu}$ minerals to predict solid-phases that are likely to be susceptible to methanotroph mediated $\mathrm{Cu}$ solubilisation. Second, growth patterns and sMMO activities are assessed for two $\mathrm{Cu}$ minerals with differing mb-Cu dissolution traits to examine how dissolution translates to observed cell activity. sMMO activity was used here as a discriminator of MMO activity because it is only expressed when inadequate $\mathrm{Cu}$ is available to sustain pMMO (Murrell et al., 2000). Further, sMMO activity is easy to measure (DiSpirito et al., 1998); it is often favoured over the pMMO in bioremediation because of its broad substrate range (Hanson and Hanson, 1996); and MMO activity is more closely related to actual methanotroph function than signatures of gene expression, which we have examined previously (Knapp et al., 2007). Finally, dialysis systems were used to assess whether direct cell and-or mb contact differentially enhances or restricts $\mathrm{Cu}$ uptake for the two minerals.

\section{Materials and methods}

\subsection{Methanobactin production}

M. trichosporium $\mathrm{OB} 3 \mathrm{~b}$ was grown in $\mathrm{Cu}$-free nitrate mineral salt medium (NMS) in 51 bioreactors (Sartorius, UK) to produce mb for subsequent growth experiments (Fox et al., 1990; Tellez et al., 1998). The organisms were grown as batch cultures at $28^{\circ} \mathrm{C}$, mixed at $200 \mathrm{rpm}$, and supplied with $\sim 60 \mathrm{ml} \mathrm{min}^{-1} \mathrm{CH}_{4}$ (BOC, UK) to sustain $\sim 4 \%$ head space $\mathrm{CH}_{4}$ levels. Typically, cultures were grown to an optical density at $600 \mathrm{~nm}\left(\mathrm{OD}_{600}\right)$ of $\sim 1.0$ at which time 31 of media was removed for $\mathrm{mb}$ harvesting. The reactor was refilled with fresh media and the culture re-grown for harvesting again. Spent media were centrifuged (Cryofuge 5500i, DJB Labcare Ltd, UK) at $5600 \times g$ for $60 \mathrm{~min}$ and the supernatant was vacuum filtered through a $0.45 \mu \mathrm{m}$ membrane filter (Gelman, USA) to remove residual solids. The $\mathrm{mb}$ fraction was separated using reversed-phase $\mathrm{C}_{18}$ solid-phase extraction (SPE) cartridges (SEP-Pak plus 55-105 $\mu \mathrm{m}$, Waters, UK), eluted with $60 \%$ acetonitrile ( $99.9 \%$, Fisher Scientific, UK), and lyophilised for storage and use. Mb quality was verified during processing using UV-Vis spectrophotometry and relative product purity was determined by high resolution HPLC (El Ghazouani et al., 2011).

\subsection{Growth on different $\mathrm{Cu}$ sources}

Growth of M. trichosporium OB3b was compared among three $\mathrm{Cu}$ sources; $\mathrm{CuCO}_{3} \cdot \mathrm{Cu}(\mathrm{OH})_{2}$ (Malachite), $\mathrm{CuO}$ (Tenorite) and $\mathrm{CuCl}_{2} \cdot \mathrm{CuCO}_{3} \cdot \mathrm{Cu}(\mathrm{OH})_{2}$ and $\mathrm{CuO}$ were chosen for growth studies from five possible minerals (also including $\mathrm{Cu}_{2} \mathrm{O}, \mathrm{Cu}_{2} \mathrm{~S}$ and $\mathrm{Cu}$-doped $\mathrm{SiO}_{2}$ ) because they are common in nature; they interact differently with $\mathrm{mb}$ in mineral binding experiments (Supplement; Fig. S1); and they have different aqueous $\mathrm{Cu}$ concentrations at equilibrium as predicted by PHREEQC geochemical modelling (see Table 1; Parkhurst and Appelo, 1999). Further, $\mathrm{Cu}_{2} \mathrm{~S}$ and $\mathrm{Cu}-$ doped $\mathrm{SiO}_{2}$ were found to interfere with the sMMO activity assay (see below). $\mathrm{CuCl}_{2}$ was used as the "soluble-Cu" control control for comparisons.

The growth experiments were performed using analytical grade $\mathrm{Cu}$ sources (Sigma-Aldrich, $\mathrm{UK}$ ), provided at levels ranging from 0 to $500 \mu \mathrm{moll}^{-1}$ total-Cu in $200 \mathrm{ml} \mathrm{NMS}$ media in 11 septum-flasks (always $n>3$ ). Each flask was provided equal volumes of mid-exponential phase $M$. trichosporium OB3b with elevated SMMO activity (typically $>400 \mathrm{ng}$ of napthol $\mathrm{min}^{-1} \mathrm{mg}_{\text {cells }}{ }^{-1}$ ) to achieve a common initial $\mathrm{OD}_{600}$ among treatments. sMMO activity was quantified using the standard liquid naphthalene-naphthol assay (DiSpirito et al., 1998), which was developed from the original sMMO screening assay of Brusseau et al. (1990). The flasks were then sealed, amended with reagent grade methane ( $4 \%$ in the headspace) and placed on a shaker table (150 rpm) maintained at $28^{\circ} \mathrm{C}$ in the dark. $\mathrm{OD}_{600}$ and headspace $\mathrm{CH}_{4}$ levels were monitored over time until stationary growth was observed. No-Cu controls were maintained to confirm viability of the inoculums (data not shown).

Methane was measured by gas chromatography using a Carlo ERBA HRGC 5160 (CE instruments, UK) fitted with a Chrompak (Kinesis Ltd, UK) pot-fused silica capillary column $(30 \mathrm{~m} \times 0.32 \mathrm{~mm})$. The carrier gas was helium, and the injector $\left(250^{\circ} \mathrm{C}\right)$ and oven $\left(35^{\circ} \mathrm{C}\right)$ were maintained at constant temperature. $\mathrm{CH}_{4}$ was detected by FID (flame 
Table 1. Modelled dissolved $\mathrm{Cu}$ concentrations for aqueous solutions equilibrated with various $\mathrm{Cu}$ mineral phases $\left(25^{\circ} \mathrm{C}\right)$ calculated using the PHREEQC geochemical simulation software (Parkhurst and Appelo, 1999) ${ }^{\mathrm{a}}$.

\begin{tabular}{|c|c|c|c|c|c|c|}
\hline \multirow[b]{2}{*}{ Formula } & \multicolumn{2}{|c|}{$\begin{array}{c}\text { Cu solubility } \\
\left(\mathrm{mol} \mathrm{dm}^{-3}\right) \text { in pure water } \mathrm{pH} 7\end{array}$} & \multicolumn{2}{|c|}{$\begin{array}{c}\text { Cu solubility in } \\
\text { growth medium pH } 7\end{array}$} & \multicolumn{2}{|c|}{$\begin{array}{l}\text { Cu solubility in carbonate } \\
\text { buffered solution } \mathrm{pH} 8^{\mathrm{b}}\end{array}$} \\
\hline & $\mathrm{Cu}^{2+}$ & $\mathrm{Cu}^{1+}$ & $\mathrm{Cu}^{2+}$ & $\mathrm{Cu}^{1+}$ & $\mathrm{Cu}^{2+}$ & $\mathrm{Cu}^{1+}$ \\
\hline $\mathrm{Cu}_{2} \mathrm{~S}$ & $1.65 \times 10^{-17}$ & $2.01 \times 10^{-12}$ & $3.38 \times 10^{-10}$ & $1.50 \times 10^{-7}$ & $2.16 \times 10^{-17}$ & $1.65 \times 10^{-13}$ \\
\hline $\mathrm{Cu}_{2} \mathrm{O}$ & $5.13 \times 10^{-13}$ & $1.55 \times 10^{-8}$ & $5.74 \times 10^{-7}$ & $2.14 \times 10^{-8}$ & $4.04 \times 10^{-13}$ & $1.82 \times 10^{-9}$ \\
\hline $\mathrm{CuO}$ & $9.71 \times 10^{-7}$ & $5.52 \times 10^{-16}$ & $2.07 \times 10^{-6}$ & $2.25 \times 10^{-14}$ & $8.80 \times 10^{-7}$ & $1.23 \times 10^{-16}$ \\
\hline $\mathrm{CuCO}_{3} \cdot \mathrm{Cu}(\mathrm{OH})^{2}$ & $1.49 \times 10^{-5}$ & $2.27 \times 10^{-12}$ & $2.19 \times 10^{-5}$ & $2.40 \times 10^{-13}$ & $1.18 \times 10^{-6}$ & $7.37 \times 10^{-16}$ \\
\hline
\end{tabular}

a Equilibrium equations, constants and enthalpies of reaction were derived from the llnl database (PHREEQC v2.16 for windows) and were used to determine Cu solubility when defined solutions were equilibrated with different copper mineral phrases. Equilibrium phases used were $\left(\mathrm{Chalcocite} \mathrm{Cu} \mathrm{S}_{2}\right.$; $\mathrm{Cuprite}_{\mathrm{C}} \mathrm{Cu} \mathrm{O}_{2}$; $\mathrm{Tenorite}, \mathrm{CuO}$; and $\mathrm{Malachite}$, $\mathrm{CuCO}_{3} \cdot \mathrm{Cu}(\mathrm{OH})^{2}$.

${ }^{\mathrm{b}}$ Experimental conditions employed in $\mathrm{Cu}$-mineral binding experiments (see Supplement).

ionization detection) and quantified on the basis of peak area calibrated using $\mathrm{CH}_{4}$ standards (Scientific \& Technical

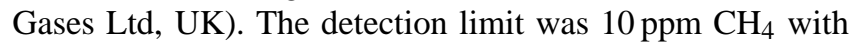
typical relative standard deviation on the calibration curves of $<1 \%$.

\subsection{Assessing the influence of cell-mineral contact and mb on cell growth and SMMO activity}

Preliminary experiments showed that $M$. trichosporium OB3b growth patterns differed depending upon $\mathrm{Cu}$ source; however, it was not clear whether cell contact and-or mb significantly influenced observed behaviour. Therefore, further experiments were performed using molecular sieve dialysis bags to assess the need for contact among mb, the cells, and the minerals to sustain growth and activity. In these experiments, inoculate cultures were grown as in the previous experiments; however, either $<1000 \mathrm{Da}$ or $<2000 \mathrm{Da}$ pore size dialysis bags (Medicell International Ltd, UK) also were included in the culture flasks. These sieve sizes were chosen because they bracket the molecular weight of $\mathrm{Cu}-\mathrm{mb}$ (i.e. $\sim 1215 \mathrm{Da}$ ), which means that they relatively exclude or allow mb to cross the membrane barrier, respectively.

Three types of dialysis experiments were performed. In all cases, $\mathrm{CuO}$ or $\mathrm{CuCO}_{3} \cdot \mathrm{Cu}(\mathrm{OH})_{2}$ was provided at $50 \mu$ moles total- $\mathrm{Cu}^{-1}$ inside the dialysis bag and the culture placed outside of the bag within the flasks. Depending upon the experiment, supplemental mb also was provided to the culture, and appropriate controls were maintained for comparison (e.g. no mineral, no mb). The first experiment assessed sMMO activity, $\mathrm{OD}_{600}$, and $\mathrm{CH}_{4}$ levels over time $(\sim 60 \mathrm{~h})$ in OB3b cultures that initially had sMMO activity. The cells were inoculated outside of $<1000 \mathrm{Da}$ dialysis bags, whereas minerals were placed inside or outside the bags. The second experiment was the same as the first except the inoculate culture had no detectable sMMO activity ( $<10 \mathrm{ng}$ of napthol $\mathrm{min}^{-1} \mathrm{mg}$ cells ${ }^{-1}$ ), implicitly meaning it had pMMO activity (Murrell et al., 2000). The goal here was to assess whether direct cell-mineral contact affected growth and sMMO activity without supplementary mb.

The third experiment used the same design as the first (i.e. cells with initial sMMO activity) except $<2000$ Da dialysis bags were used and supplemental mb was provided outside the bags in some flasks. This experiment was shorter than the earlier experiments $(\sim 24 \mathrm{~h})$ because the goal was to assess the role of additional mb on sMMO activity, and it was shortened to reduce the impact of new mb production on cell activity during the experiment. Supplemental mb was provided at a $\sim 1: 1 \mathrm{mb}$ :total $\mathrm{Cu}$ molar ratio to half of the flasks and no additional mb provided to the others, and sMMO activity, $\mathrm{CH}_{4}$ levels, and $\mathrm{OD}_{600}$ were monitored over time.

In this latter experiment, soluble $\mathrm{Cu}$ versus cellular $\mathrm{Cu}$ was quantified at the end of the experiment according to previous methods (Fitch et al., 1993; Yu et al., 2009). Briefly, $10 \mathrm{ml}$ of bulk solution was centrifuged at $12000 \times g$ for $10 \mathrm{~min}$ and the supernatant was retained as "soluble $\mathrm{Cu}$ ". The pellet was resuspended in $10 \mathrm{ml}$ of $\mathrm{Cu}$-free, $10 \mathrm{mM}$ EDTA solution (pH 7.0) and agitated at $200 \mathrm{rpm}$ for $1 \mathrm{~h}$ at $28^{\circ} \mathrm{C}$. This solution was centrifuged again and the supernatant was assumed to be surface-associated $\mathrm{Cu}$. The resulting pellet was washed and centrifuged three times in deionised water and then suspended in 3-ml deionised water and freeze-dried. The dried cells were dissolved in $\mathrm{HCl}(37.5 \% \mathrm{w} / \mathrm{w} ; 1 \mathrm{ml})$ and diluted to $10 \mathrm{ml}$ again in deionised water. "Cellular $\mathrm{Cu}$ " was defined as the surfaced-associated $\mathrm{Cu}$ plus the $\mathrm{Cu}$ present in the final dried pellet.

$\mathrm{Cu}$ from each fraction was analysed using a Varian Vista MPX Inductively Coupled Plasma - Optical Emission Spectrometer (ICP-OES) (Agilent Technologies, UK) and levels were normalised to the ambient cell dry mass at the time of harvesting. Calibration standards $(0.0,3.1,6.3,9.4$ and $15.7 \mu \mathrm{mol} \mathrm{l}^{-1} \mathrm{Cu}$ ) were checked against a river water reference material containing $2.4 \mu \mathrm{mol}^{-1} \mathrm{Cu}$ (LGC, UK). The detection limit for dissolved $\mathrm{Cu}$ was $0.16 \mu \mathrm{mol}^{-1} \mathrm{Cu}$ with a typical relative standard deviation for the reference material of $<10 \%$. 


\section{Results and discussion}

\subsection{Affect of different $\mathrm{Cu}$ sources on growth patterns}

$\mathrm{CuO}$ and $\mathrm{CuCO}_{3} \cdot \mathrm{Cu}(\mathrm{OH})_{2}$ were chosen for growth and activity studies based on Table 1 data and previous results (Knapp et al., 2007; Kulczycki et al., 2007; Kulczycki et al., 2011). M. trichosporium OB3b cultures with active sMMO were transferred to replicate vials containing $\mathrm{CuO}$, $\mathrm{CuCO}_{3} \cdot \mathrm{Cu}(\mathrm{OH})_{2}$ and $\mathrm{CuCl}_{2}$ containing up to $500 \mu \mathrm{mol}$ total$\mathrm{Cul}^{-1}$ and growth was monitored over time. Growth rate was very similar for $\mathrm{CuO}$ and $\mathrm{CuCO}_{3} \cdot \mathrm{Cu}(\mathrm{OH})_{2}$ and no lag phase was observed (Fig. 1a and b). However, only $2.5 \mu \mathrm{mol}$ total- $\mathrm{Cu}{ }^{-1}$ as $\mathrm{CuCl}_{2}$ caused a significant growth lag in the culture (Fig. 1c), which has been seen previously in M. trichosporium $\mathrm{OB} 3 \mathrm{~b}$ with active sMMO and soluble $\mathrm{Cu}$ (Kim et al., 2005). Clearly, the two solid-phase $\mathrm{Cu}$ sources restrict $\mathrm{Cu}$ release into solution allowing unaffected cell growth at very high $\mathrm{Cu}$ levels with no sign of toxicity.

To determine how sMMO activity was influenced by each $\mathrm{Cu}$ addition, single sMMO activity assays were performed on each culture during late-exponential phase. sMMO activity was not detectable in any cultures supplemented with $\mathrm{CuCO}_{3} \cdot \mathrm{Cu}(\mathrm{OH})_{2}$ or $\mathrm{CuCl}_{2}$, but sMMO activity was prevalent with $\mathrm{CuO}$ up to $50 \mu$ mol total-Cu ${ }^{-1}$. Cu dissolution from $\mathrm{CuO}$ was, therefore, not sufficient to repress sMMO activity (i.e. to provide $\mathrm{Cu}$ for switchover to $\mathrm{pMMO}$ activity), whereas $\mathrm{Cu}$ release from $\mathrm{CuCO}_{3} \cdot \mathrm{Cu}(\mathrm{OH})_{2}$ and $\mathrm{CuCl}_{2}$ was sufficient to repress sMMO activity, which is consistent with $\mathrm{Cu}$ dissolution trends predicted for the two mineral phases (Table 1).

\subsection{Effect of mineral-cell contact on SMMO activity}

Further growth and activity experiments were performed to verify the previously observed influence of the two $\mathrm{Cu}$ minerals on sMMO activity (Sect. 3.1). Specifically, activity was assessed under different culture conditions, including systems that restrict direct cell-mineral contact and also with supplemental mb. Previous results showed that mb interactions with $\mathrm{Cu}$ silicates quenched the surface of the mineral, suppressing $\mathrm{Cu}$ release and allowing sMMO-related gene expression, even when $\mathrm{Cu}$ levels were high (Knapp et al., 2007; Kulczycki et al. 2007; Kulczycki et al., 2011). Therefore, we speculated that mb mediation and cell surface interactions might also explain differences between $\mathrm{CuCO}_{3} \cdot \mathrm{Cu}(\mathrm{OH})_{2}$ and $\mathrm{CuO}$ relative to sMMO activity. As such, $M$. trichosporium OB3b was grown in flasks containing selectively permeable barriers (i.e. dialysis bags) that allowed the cells, mb and the minerals to be separated in combinations to delineate how $\mathrm{mb}$, mineral, and surface contact affect activity.

The two initial experiments were performed using dialysis flask systems without amended mb. The first experiment inoculated $M$. trichosporium $\mathrm{OB} 3 \mathrm{~b}$ cultures with strong sMMO activity $\left(\sim 600 \mathrm{ng}\right.$ of napthol $\left.\mathrm{min}^{-1} \mathrm{mg} \mathrm{cells}^{-1}\right)$ into
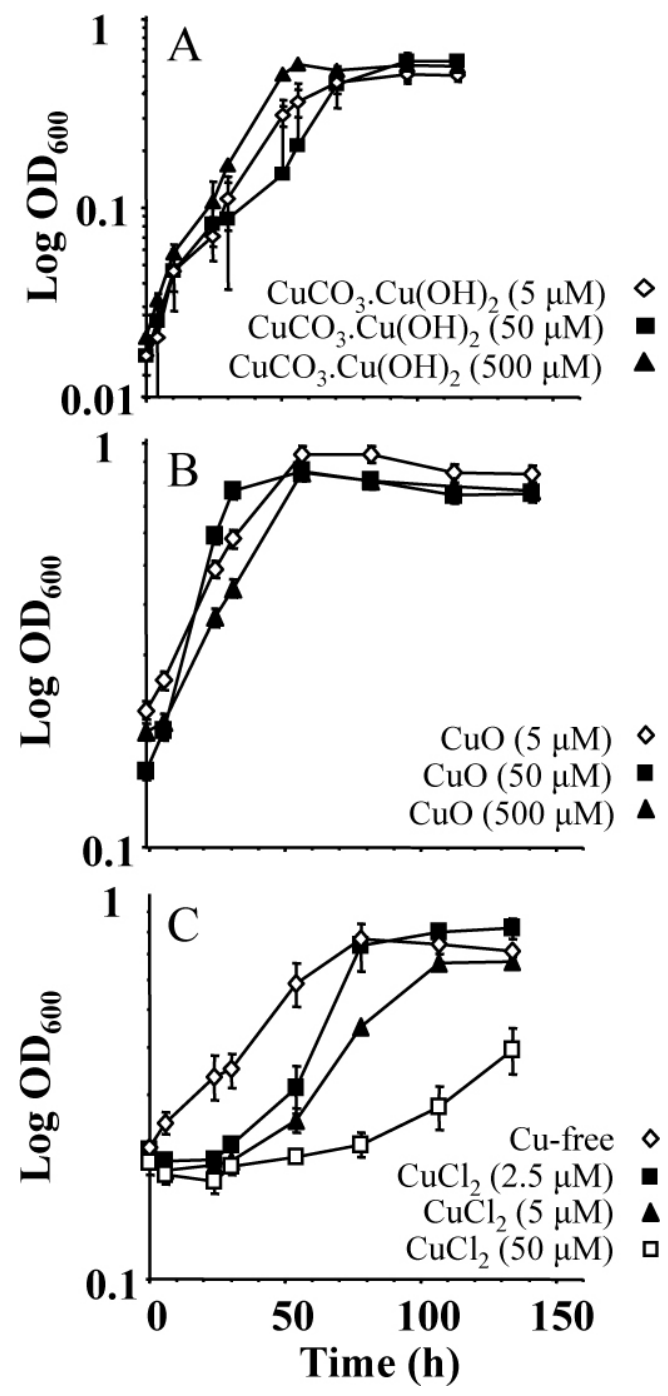

Fig. 1. Effect of $\mathrm{Cu}$ source and concentration on the growth of Methylosinus trichosporium OB3b. Error bars represent standard deviations $(n=3)$.

duplicate flasks containing each mineral at $50 \mu \mathrm{mol}$ total$\mathrm{Cul}^{-1}$, where the mineral was located inside and outside of dialysis bags (pore size $<1000 \mathrm{Da}$ ). In theory, if direct contact between the cells and the mineral was needed for $\mathrm{Cu}$ uptake, sMMO activity would be retained when the minerals and cells were separated because mineral-Cu would not readily cross a $<1000 \mathrm{Da}$ barrier. The $<1000 \mathrm{Da}$ dialysis bags were explicitly used to block new mb produced by the cells during the experiment that might confound any cell-mineral surface dependent interactions. Preliminary tests were performed on the dialysis bags to verify that the bags themselves did not affect sMMO activity and no significant difference in sMMO activity was measured with just bags present (Supplement, Fig. S2).

When the cells and $\mathrm{CuO}$ were separated by the dialysis bags, significant SMMO activity was perpetuated over time 

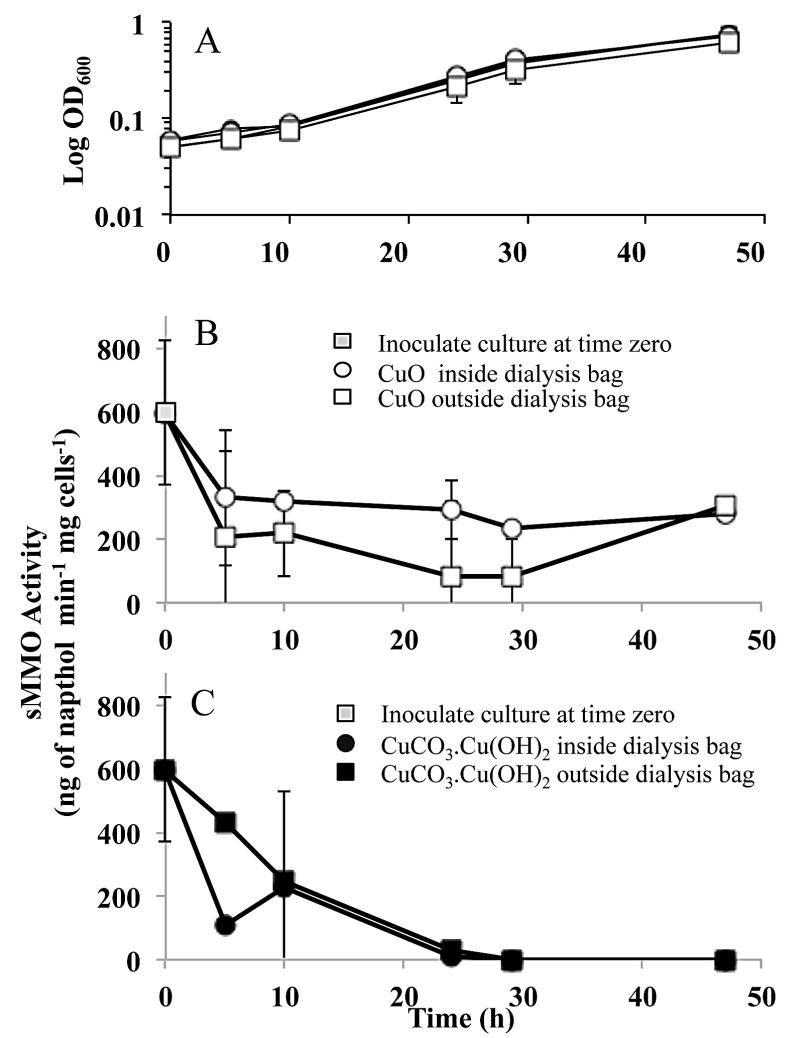

Fig. 2. Affect of direct mineral contact on the maintenance of sMMO activity (ng of napthol $\mathrm{min}^{-1} \mathrm{mg}$ cell dry weight ${ }^{-1}$ ) when the initial culture has sMMO activity. (A) Growth curves for $\mathrm{CuO}$ and $\mathrm{CuCO}_{3} \cdot \mathrm{Cu}(\mathrm{OH})_{2}$ at $50 \mu \mathrm{mol}$ total- $\mathrm{Cu}^{-1}$ where the mineral was inside and outside of $<1000$ Da sieve size dialysis bags in the culture flask ( $n=2$ per treatment). (B) sMMO activity over time as function of location of $\mathrm{CuO}$; i.e. inside and outside of the dialysis bags. (C) sMMO activity over time as function of location of $\mathrm{CuCO}_{3} . \mathrm{Cu}(\mathrm{OH})_{2}$; i.e. inside and outside of the dialysis bags. Error bars represent standard deviations $(n=3)$.

in the cells, implying $\mathrm{Cu}$ is not readily available from this mineral without intimate contact (Fig. 2b). However, when direct contact was permitted, sMMO activity initially declined, but after $47 \mathrm{~h}$, activity recovered to the same level as when contact was not allowed. This implies that $\mathrm{Cu}$ is more available from $\mathrm{CuO}$ with direct cell-mineral contact, but as cell densities increase (Fig. 2a), Cu dissolution is likely too slow to supply sufficient $\mathrm{Cu}$ for the growing culture. In contrast, sMMO activity was completely suppressed by $\mathrm{CuCO}_{3} \cdot \mathrm{Cu}(\mathrm{OH})_{2}$ after $30 \mathrm{~h}$, regardless of cell-mineral contact (Fig. 2c). Apparently, $\mathrm{Cu}$ dissolution from this mineral is sufficiently rapid to supply available $\mathrm{Cu}$ across the dialysis barrier, suggesting direct contact is not as critical for cells to obtain $\mathrm{Cu}$ from $\mathrm{CuCO}_{3} \cdot \mathrm{Cu}(\mathrm{OH})_{2}$.

To corroborate Fig. 2 results, a second experiment was performed with $<1000 \mathrm{Da}$ dialysis bags, but in this case, the inoculate OB3b culture had no detectable sMMO activity.

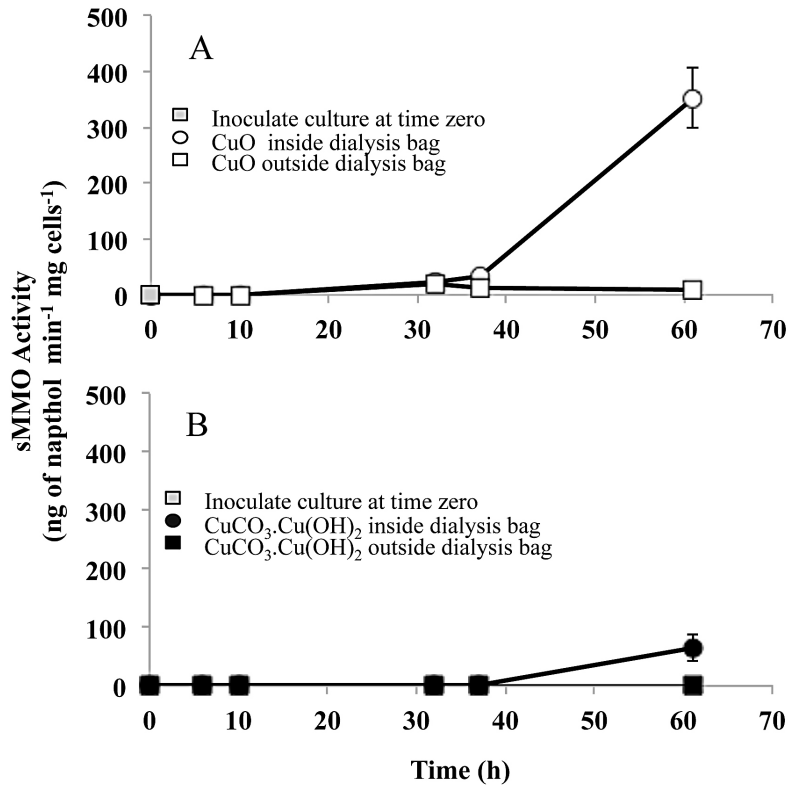

Fig. 3. Affect of direct mineral contact on the formation of sMMO activity ( $\mathrm{ng}$ of napthol $\mathrm{min}^{-1} \mathrm{mg}$ cell dry weight ${ }^{-1}$ ) when the initial culture does not have sMMO activity. sMMO activity presented over time as function of location of the two minerals, (A) $\mathrm{CuO}$ and (B) $\mathrm{CuCO}_{3} \cdot \mathrm{Cu}(\mathrm{OH})_{2}$; i.e. inside and outside of $<1000 \mathrm{Da}$ sieve size dialysis bags. sMMO activity is initially not present, but sMMO activity appears as cell density increases, especially for $\mathrm{CuO}$ without direct cell-mineral contact. Mean specific growth rates for the cultures range from 0.45 to $0.50 \mathrm{~h}^{-1}$. Error bars represent standard deviations $(n=3)$.

Here we monitored the development of sMMO activity over time as the culture densities increased as an indicator of $\mathrm{Cu}$ non-availability. Initially, no sMMO activity was apparent in any culture (with or without direct cell-mineral contact; Fig. 3). However, Fig. 3a shows that strong sMMO activity ultimately developed as the culture density increased with $\mathrm{CuO}$ and no direct cell contact (curves not shown), which is consistent with Fig. 2b. However, when $\mathrm{CuCO}_{3} \cdot \mathrm{Cu}(\mathrm{OH})_{2}$ was the $\mathrm{Cu}$ source, no sMMO activity was detectable until the late growth phase of the experiment (Fig. 3b). Interestingly, a trace level of sMMO activity became detectable when $\mathrm{CuCO}_{3} \cdot \mathrm{Cu}(\mathrm{OH})_{2}$ was inside the dialysis bag, suggesting cell mineral contact may slightly enhance $\mathrm{Cu}$ availability, although this influence is less pronounced than for $\mathrm{CuO}$. Typical cell growth curves for all dialysis experiments are provided in Fig. 2a, showing that growth lags were not observed for either mineral at $50 \mu \mathrm{mol}$ total- $\mathrm{Cu} \mathrm{l}^{-1}$. In addition, growth rates were similar among treatments. 


\subsection{Effect of mb on sMMO activity and Cu uptake from different minerals}

The previous experiments showed that direct cell-mineral contact increased $\mathrm{Cu}$ availability, especially with $\mathrm{CuO}$. However, the use of $<1000 \mathrm{Da}$ dialysis bags did not allow $\mathrm{mb}$ to directly mediate $\mathrm{Cu}$ acquisition. To assess the possible role of extracellular mb in Cu supply, a third experiment was performed in which $<2000 \mathrm{Da}$ dialysis bags were substituted for the $<1000 \mathrm{Da}$ bags, and supplemental $\mathrm{mb}$ was provided to some flasks. sMMO activity declined after $6 \mathrm{~h}$ with both minerals with and without supplemental mb (Fig. 4). However, cells exposed to $\mathrm{CuO}$ without supplemental $\mathrm{mb}$ retained three times greater sMMO activity after $24 \mathrm{~h}$ relative to the other treatments. Further, when no excess mb was provided to $\mathrm{CuO}$, cellular $\mathrm{Cu}$ was not detected $(<0.1 \mu \mathrm{g}-\mathrm{Cu} / \mathrm{mg}$-cell dry weight), implying that little $\mathrm{Cu}$ was being internalised by the cells. In contrast, when $\mathrm{CuCO}_{3} \cdot \mathrm{Cu}(\mathrm{OH})_{2}$ was the $\mathrm{Cu}$ source, sMMO activity decreased independent of mb supply, and cellular $\mathrm{Cu}$ levels increased substantially (Fig. 4). $\mathrm{CuCO}_{3} \cdot \mathrm{Cu}(\mathrm{OH})_{2}$ readily provides $\mathrm{Cu}$ to $M$. trichosporium OB3b, both suppressing sMMO activity and facilitating $\mathrm{Cu}$ uptake into the cell, whereas mb mediation and direct contact are important for $\mathrm{Cu}$ uptake from $\mathrm{CuO}$.

\subsection{Growth kinetics of M. trichosporium OB3b on mineral $\mathrm{Cu}$ sources with and without $\mathrm{mb}$}

Specific growth rates and cell yields were calculated for all experiments with and without excess $\mathrm{mb}$ for $M$. trichosporium $\mathrm{OB} 3 \mathrm{~b}$ grown in the presence of $\mathrm{CuO}$ or $\mathrm{CuCO}_{3} \cdot \mathrm{Cu}(\mathrm{OH})_{2}\left(50 \mu \mathrm{mol}\right.$ total-Cu $\left.{ }^{-1}\right)$. Overall, excess $\mathrm{mb}$ did not alter cell yields for the minerals $(0.011 \pm 0.005$ and $0.010 \pm 0.003 \mathrm{mg}$ cell dry weight $/ \mathrm{mg} \mathrm{CH}_{4}$ with and without $\mathrm{mb}$, respectively; mean $\pm 95 \%$ confidence interval). However, mb significantly increased growth rates $(p<0.05$, Wilcoxon signed-rank test). The mean specific growth rate coefficient with mb was $0.055 \pm 0.007 \mathrm{~h}^{-1}$, whereas the coefficient was $0.044 \pm 0.006 \mathrm{~h}^{-1}$ without $\mathrm{mb}$, which implies that mb enhances cell growth on these solid-phase $\mathrm{Cu}$ minerals, regardless of whether sMMO or pMMO activity prevails in the cells.

\subsection{Role of $\mathrm{mb}$ in cell growth on solid-phase mineral $\mathrm{Cu}$ sources}

$\mathrm{Mb}$ is known to play multiple roles relative to $\mathrm{Cu}$ supply in M. trichosporium OB3b (Fitch et al., 1993; Zahn and DiSpirito, 1996; DiSpirito et al., 1998; Kim et al., 2005; Knapp et al., 2007; Kulczycki et al., 2007; Balasubramanian and Rosenzweig, 2008; Choi et al., 2008; Kulczycki et al., 2011). However, results here show that the influence of $\mathrm{mb}$ on cell growth in the natural environment depends on solid-phase $\mathrm{Cu}$ conditions. For example, for relatively insoluble $\mathrm{Cu}$ sources, such as some silicates, mb does not enhance $\mathrm{Cu}$ acquisition

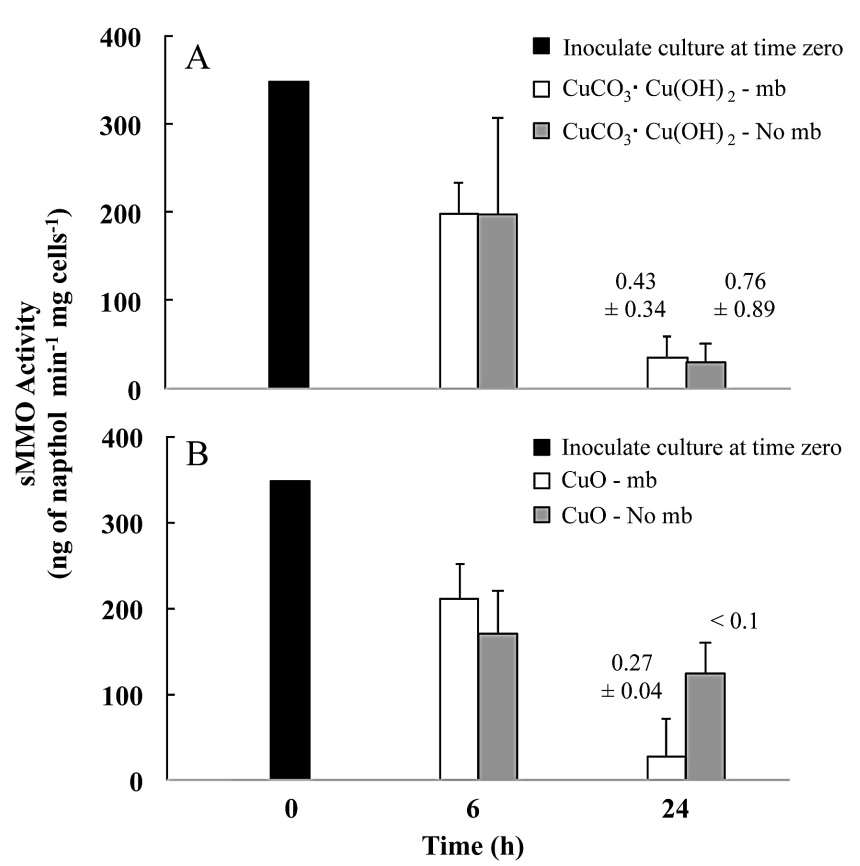

Fig. 4. sMMO activity (ng of napthol formed $\min ^{-1} \mathrm{mg}$ cell dry weight ${ }^{-1}$ ) for $M$. trichosporium OB3b with and without supplemental methanobactin in the presence of (A) $\mathrm{CuCO}_{3} \cdot \mathrm{Cu}(\mathrm{OH})_{2}$ and (B) $\mathrm{CuO}$ confined in $<2000 \mathrm{Da}$ sieve size dialysis bags. Concentration of cellular $\mathrm{Cu}$ after $24 \mathrm{~h}$ is annotated above columns (as $\mu \mathrm{g}-\mathrm{Cu} / \mathrm{mg}$ cell dry weight \pm standard deviation). Error bars represent standard deviation $(n=3)$. Mean specific growth rates for the cultures range from 0.36 to $0.50 \mathrm{~h}^{-1}$.

and may actually quench the release of $\mathrm{Cu}$ from such surfaces (Kulczycki et al., 2007, Kulczycki et al., 2011). Whereas, M. trichosporium $\mathrm{OB} 3 \mathrm{~b}$ readily acquires $\mathrm{Cu}$ from more soluble minerals, such as $\mathrm{CuCO}_{3} \cdot \mathrm{Cu}(\mathrm{OH})_{2}$. For such minerals it is not yet clear whether mb is actually needed for $\mathrm{Cu}$ uptake; however, we suspect mb must play some role, possibly through toxicity suppression by binding to free $\mathrm{Cu}$ (I) (Kim et al., 2005; El Ghazouani et al., 2011). In fact, M. trichosporium $\mathrm{OB} 3 \mathrm{~b}$ grows well on $\mathrm{CuCO}_{3} \cdot \mathrm{Cu}(\mathrm{OH})_{2}$, particularly at very high $\mathrm{Cu}$ levels; the mineral appears to act as a "controlled release" $\mathrm{Cu}$ source, allowing the cell to obtain enough $\mathrm{Cu}$ for growth, but at a supply rate that does not cause toxicity.

In contrast, mb appears to play a more central role in $\mathrm{Cu}$ supply for growth with $\mathrm{CuO}$, a more sparingly soluble mineral (Table 1). Mb remotely obtains $\mathrm{Cu}$ from this mineral, returning $\mathrm{Cu}$ to the cell, suppressing sMMO activity, and increasing cellular Cu levels (Fig. 4b). Further, direct cell contact with $\mathrm{CuO}$ enhances $\mathrm{Cu}$ availability (Figs. 2a and 3a). Clearly, the two minerals investigated differ in their capacity (and maybe mechanism) for $\mathrm{Cu}$ supply to $M$. trichosporium $\mathrm{OB} 3 \mathrm{~b}$, which indicates differences in $\mathrm{Cu}$ mineralogy influence in situ MMO activity (i.e. sMMO vs. pMMO). 
Although $\mathrm{mb}$ affects $\mathrm{Cu}$-related responses differently among minerals (Figs. 2-4), mb also appears to act as a mild growth stimulant in the presence of solid-phase $\mathrm{CuO}$ and $\mathrm{CuCO}_{3} \cdot \mathrm{Cu}(\mathrm{OH})_{2}$. Interestingly, this stimulatory effect does not appear to depend on whether pMMO or sMMO is the active MMO in the cell. Whether this effect results from $\mathrm{Cu}$ toxicity suppression, enhanced $\mathrm{Cu}$ bioavailability after release, or something more speculative is not known (e.g. quorum signalling seen with similar molecules; Miller and Bassler, 2001; D’Onofrio et al., 2010).

\section{Conclusions}

This work shows that solid-phase $\mathrm{Cu}$ minerals readily support growth in $M$. trichosporium $\mathrm{OB} 3 \mathrm{~b}$ and that mb conditionally plays an important role in that activity. In fact, new data here suggest solid $\mathrm{Cu}$ sources maybe be superior to more soluble sources, which is actually not surprising because methanotrophs usually reside in environments where $\mathrm{Cu}$ is less available, such as soils. However, the active MMO in the cells differs depending upon the $\mathrm{Cu}$ source; pMMO activity is sustained with $\mathrm{CuCO}_{3} \cdot \mathrm{Cu}(\mathrm{OH})_{2}$, whereas sMMO activity prevails with $\mathrm{CuO}$ unless available $\mathrm{Cu}$ :cell ratios are high or the mineral is proximally close to the cells.

Observations here have significant practical implications. First, results suggest a strategy for promoting (or explaining) sMMO activity in biotechnical applications, such as contaminant degradation (Oldenhuis et al., 1989; Kim and Graham, 2003; Lee et al., 2006). If $\mathrm{Cu}$ is provided or is presented in a sparingly soluble form, favoured sMMO activity will prevail. Furthermore, previous field work has not found correlations between in situ $\mathrm{Cu}$ level and methanotroph activity, despite obvious links between $\mathrm{Cu}$ and methanotroph function. However, our data show that differences in $\mathrm{Cu}$ mineralogy potentially explain why soil- $\mathrm{Cu}$ and methanotroph activity have not been correlated in past studies. Therefore, our results suggest mineralogical assessment is essential for explaining MMO activity in natural systems. Regardless, mb and $\mathrm{Cu}$ mineralogy now should be added to $\mathrm{CH}_{4}, \mathrm{O}_{2}$ and nitrogen as key regulators of in situ aerobic $\mathrm{CH}_{4}$ metabolism (Graham et al., 1993; Hanson and Hanson, 1996), and should be considered in future field investigations, especially in terrestrial environments. $\mathrm{Mb}$ broadly stimulates growth in solid-phase $\mathrm{Cu}$ systems, whereas $\mathrm{Cu}$ mineralogy influences whether sMMO or pMMO is the active form in resident cells.

\section{Supplementary material related to this article is available online at: http://www.biogeosciences.net/8/2887/2011/ bg-8-2887-2011-supplement.pdf.}

Acknowledgements. This work was supported by grant NE/F00608X/1 from the Natural Environment Research Council NERC. We thank Vasile Lavric for assistance on some of the kinetic analysis and Charles Knapp for advice on methanotroph culturing.

Edited by: K. Küsel

\section{References}

Balasubramanian, R. and Rosenzweig, A. C.: Copper methanobactin: a molecue whose time has come, Curr. Opin. Chem. Biol., 12, 245-249, 2008.

Balasubramanian, R., Levinson, B. T., and Rosenzweig, A. C.: Secretion of flavins by three species of methanotrophic bacteria, Appl. Environ. Microbiol., 76, 7356-7358, 2010.

Behling, L., Hartsel, S. C., Lewis, D. E., DiSpirito, A. A., Choi, D. W., Masterson, L. R.,Veglia, G., and Gallagher W. H.: NMR, mass spectrometry and chemical evidence reveal a different structure of methanobactin that contains oxazolone rings, J. Am. Chem. Soc., 130, 12604-12605, 2008.

Berson, O. and Lidstöm, M. E.: Study on copper accumulation by the type 1 methanotroph Methylomicrobium albus BG8, Environ. Sci. Technol., 30, 802-809, 1996.

Brusseau, G. A., Tsien, H-C., Hanson, R. S., and Wackett, L. P.: Optimization of trichloroethylene oxidation by methanotrophs and the use of a colorimetric assay to detect soluble methane monooxygenase activity, Biodegradation, 1, 19-29, 1990.

Choi, D. W., Do, Y. S., Zea, C. J., McEllistrem, M. T., Lee, S. W., Semrau, J. D., Pohl, N. L., Kisting, C. J., Scardino, L. L., Hartsel, S. C., Boyd, E. S., Geesey, G. G., Riedel, T. P., Shafe, P. H., Kranski, K. A., Tritsch, J. R., Antholine, W. E., and DiSpirito, A. A.: Spectral and thermodynamic properties of $\mathrm{Ag}(\mathrm{I}), \mathrm{Au}(\mathrm{III})$, $\mathrm{Cd}(\mathrm{II}), \mathrm{Co}(\mathrm{II}), \mathrm{Fe}$ (III), Hg(II), Mn(II), Ni(II), Pb(II), U(IV), and $\mathrm{Zn}$ (II) binding by methanobactin from Methylosinus trichosporium OB3b, J. Inorg. Biochem., 100, 2150-2161, 2006.

Choi, D. W., Semrau, J. D., Antholine, W. E., Hartsel, S. C., Anderson, R. C., Carey, J. N., Dreis, A. M., Kenseth, E. M., Renstrom, J. M., Scardino, L. 1., Van Gorden, G. S., Volkert, A. A., Wingad, A. D., Yanzer, P. J., McEllistrem, M. T., de la Mora, A. M., and DiSpirito, A. A.: Oxidase, superoxide dismutase, and hydrogen peroxide reductase activities of methanobactin from types I and II methanotrophs, J. Inorg. Biochem., 102, 1571-1580, 2008.

DiSpirito, A. A., Zahn, J. A., Graham, D. W., Kim, H. J., Larive, C. K., Derrick, T. S., Cox, C. D., and Taylor, A.: Copper-binding compounds from Methylosinus trichosporium OB3b, J. Bacteriol., 180, 3606-3613, 1998.

D’Onofrio A., Crawford, J. M., Stewart, E. J., Witt, K., Gavrish, E., Epstein, S. Clardy, J., and Lewis, K.: Siderophores from neighboring organisms promote the growth of uncultured bacteria, Chem. Biol., 17, 254-264, 2010.

El Ghazouani, A., Basle, A., Firbank, S. J., Knapp, C. W., Gray, J., Graham, D. W., and Dennison C.: Copper-binding properties and structures of methanobactins and Methylosinus trichosporium OB3b, Inorg. Chem., 50, 1378-1391, 2011.

Fitch, M. W., Graham, D. W., Arnold, R. G., Agarwal, S. K., Phelps, P., Speitel Jr., G. E., and Georgiou, G.: Phenotypic characterization of copper-resistant mutants of Methylosinus trichosporium OB3b, Appl. Environ. Microbiol., 59, 2771-2776, 1993. 
Fox, B. G., Froland, W. A., Jollie, D. R., and Lipscomb, J. D.: Methane monooxygenase from Methylosinus trichosporium OB3b, Methods Enzymol., 188, 191-202, 1990.

Fuerstenau, D. W., Herrera-Urbina, R., and McGlashan, D. W.: Studies on the applicability of chelating agents as universal collectors for copper minerals, Int. J. Min. Proc., 58, 15-33, 2000.

Graham, D. W. and Kim H. J.: Production, isolation, purification and functional characterisation of methanobactins, in: Methods Enzymol., 495, 227-246, 2011.

Graham, D. W., Chowdhary, J. A., Hanson, R. S., and Arnold, R. G.: Factors Affecting Competition Between Type I and Type II Methanotrophs in Continuous-Flow Reactors, Microbial. Ecol., 26, 1-17, 1993.

Hanson, R. S. and Hanson T. E.: Methanotrophic Bacteria, Microbiol. Rev., 60, 439-471, 1996.

Kim, H. J. and Graham, D. W.: Effects of Oxygen and Nitrogen Conditions on the Transformation Kinetics of 1,2Dichloroethenes by Methylosinus trichosporium OB3b and its sMMO $^{C}$ Mutant, Biodegradation, 14, 407-414, 2003.

Kim, H. J., Graham, D. W, DiSpirito, A. A., Alterman, M. A., Galeva, G., Larive, C. K., Asunskis, D., and Sherwood, P. M. A.: Methanobactin, a copper-acquisition compound from methaneoxidizing bacteria, Science, 305, 1612-1615, 2004.

Kim, H. J., Galeva, N., Larive, C. K., Alterman, M., and David, W.: Purification and Physical-chemical properties of methanobactin: A chalkophore from Methylosinus trichosporium OB3b, Biochem., 44, 5140-5148, 2005.

Knapp, C. W., Fowle, D. A., Kulczycki, E., Roberts, J. A., and Graham, D. W.: Methane monooxygenase gene expression mediated by methanobactin in the presence of mineral copper sources, Proc. Nat. Acad. Sci. USA, 104, 12040-12045, 2007.

Krentz, B. D., Mulheron, H. J., Semrau, J. D., DiSpirito, A. A., Bandow, N. L., Haft, D. H., Vuilleumier, S., Murrell, J. C., McEllistrem, M. T., Hartsel, S. C., and Gallagher, W. H.: Comparison of methanobactins from Methylosinus trichosporium OB3b and Methylocystis strain SB2 predicts methanobactins are synthesized from diverse peptide precursors modified to create a common core for binding and reducing copper ions, Biochem. 49, 10117-10130, 2010.

Kulczycki, E., Fowle, D. A., Knapp, C., Graham, D. W., and Roberts, J. A.: Methanobactin-promoted dissolution of $\mathrm{Cu}$ substituted borosilicate glass, Geobiol. 5, 251-263, 2007.

Kulczycki, E., Fowle, D. A., Kenward, P. A., Leslie, K., Graham, D. W., and Roberts, J. A.: Stimulation of methanotroph activity by $\mathrm{Cu}$-substituted borosilicate glass, Geomicrobiol. J., 28, 1-10, 2011.
Lee, S. W., Keeney, D. R., Lim, D. H., Dispirito, A. A., and Semrau, J. D.: Mixed pollutant degradation by Methylosinus trichosporium OB3b expressing either soluble or particulate methane monooxygenase: can the tortoise beat the hare?, Appl. Environ. Microbiol., 72, 7503-7509, 2006.

Lieberman, R. L. and Rosenzweig, A. C.: Biological methane oxidation: Regulation, biochemistry and active site structure of particulate methane monooxygenase, Crit. Rev. Biochem. Mol. Bio., 39, 147-164, 2004.

Morton, J. D., Hayes, K. F., and Semrau, J. D.: Bioavailability of chelated and soil-adsorbed copper to Methylosinus trichosporium OB3b, Environ. Sci. Technol., 34, 4917-4922, 2000.

Miller, M. B. and Bassler, B. L.: Quorum sensing in bacteria, Annu. Rev. Microbiol., 55, 165-199, 2001.

Murrell, J. C., McDonald, I. R., and Gilbert, B.: Regulation of expression of methane monooxygenases by copper ions, Trends Microbiol., 8, 221-225, 2000.

Nguyen, H. H., Shiemke, A. K., Jacobs, S. J., Hales, B. J., Lidstrom, M. E., and Chan S. I.: The nature of the copper ions in the membranes containing the particulate methane monooxygenase from Methylococcus capsulatus (Bath), J. Biol. Chem., 269, 14995-15005, 1994.

Nriagu, J. O.: Copper in the Environment, Part I: Ecological Cycling. Wiley-Interscience, New York, 1979.

Oldenhuis, R., Vink, R. L., Janssen, D. B., and Witholt, B.: Degradation of chlorinated aliphatic hydrocarbons by Methylosinus trichosporium OB3b expressing soluble methane monooxygenase, Appl. Environ. Microbiol., 55, 2819-2826, 1989.

Parkhurst, D. L. and Appelo, C. A. J.: User's Guide to PHREEQC, Version 2: A Computer Program for Speciation, Batch-reaction, One-dimensional transport, and inverse geochemical calculations, US Geological Survey Water Resources Inv., Denver, Colorado, 99-4259, 1999.

Téllez, C. M., Gaus, K. P., Graham, D. W., Arnold, R. G., and Guzman, R. Z.: Isolation of copper biochelates from Methylosinus trichosporium OB3b and soluble methane monooxygenase mutants, Appl. Environ. Microbiol., 64, 1115-1122, 1998.

Yu, Y., Ramsay, J. A., and Ramsay, B. A.: Use of allylthiourea to produce soluble methane monooxygenase in the presence of copper, Appl. Microbiol. Biotechnol., 82, 333-339, 2009.

Zahn, J. A. and DiSpirito A. A. Membrane-associated methane monooxygenase from Methylococcus capsulatus (Bath), J. Bacteriol., 178, 1018-1029, 1996. 